\title{
ANALYZING STUDENTS' IDENTITY AND DIFFERENCE THROUGH ENGLISH MEETING CLUB
}

\author{
Suharti Sirajuddin \\ Universitas Megarezky \\ suhartisiradjuddin772@gmail.com \\ Muhammad Yahrif \\ Universitas Megarezky \\ muhyahrif@gmail.com
}

\begin{abstract}
The article aims at finding out students' learner identity and difference through English Club Meeting at Megarezky Universitas. This research investigated twenty members of English Club Meeting of Megarezky University (E-Comers) who come regularly and five respondents for interview. The method of this research is used observation, field note, and interview. The data collecting were analyzed by presented, analyzed, discussed and interpreted. The result of this research categorized four factors in order to understand learner identity, motivation, learning strategies, learner autonomy, and cross linguistic influence. In motivation, students are motivated due to the value of group community, students' personal goal, and senior members' role. While in learning strategies; coping and communication strategies are appeared on this research. Talking about learner autonomy, it is revealed that students' control is the most effective strategies. So, it can be concluded that cross-linguistic influences students in English learning process. In conclusion, these four factors help teachers to understand students' identity and difference. Every student has different motivation, learning strategies, students' autonomy and cross-linguistic influence factors which English Meeting Club tends to accommodate students' identity in one group activity.
\end{abstract}

Keywords: Students, Identity, English Meeting club

\section{A. INTRODUCTION}

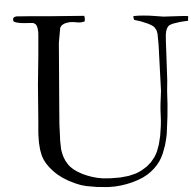

nderstanding learner identity and difference is one of important factors to achieve learning success especially for teachers or lecturers. Students' preference of learning, interest, motivation or their social background helps teachers to decide the best method and approach to teach in their class. ((Kolb \& Kolb (2012), stated the value of that the influence of understanding learners' identity had strong correlation with students success and failure.

The positive point of view for both perspective; teachers and students understanding learner identity and difference believed can increase learning success. There were several ways to investigate learners' identity, it refers to classroom interaction during teacher and students' interaction. However, sometimes formal situation had limitation to understand more about learners' identity, due to less of flexibility between teacher and students. Teachers had to follow several rules by government and school, for example, scheduling, arranging curriculum, and giving test. 
In this case, informal interaction might be an answer to find out students' learner identity and difference. English meeting club was one of informal education setting which can help identifying students' identity and difference, which almost similar in classroom interaction but the setting should be more relax and casual. Because relax and casual environment were expected to understand better learners' identity rather than through classroom interaction. In this research, it will focus on English club meeting at Megarezky University under the name EComer (English Community of Megarezky) which created by English Education study program.

The chosen context of this research was E-Comer at Megarezky University. The members of this English club were from different study program at Megarezky university which had twenty three study programs. However, most members on this club meeting were English Education study program. There were approximately thirty students attending in every meeting, which women were more dominant than men as participants on this club meeting. They had different topic in every meeting and coordinate by the member of committee of E-Comer. Every regular member had schedule as a presenter and lead the meeting with one topic which had released one day before the meeting day. Topic was chosen to challenge members to speak and communicate actively during the meeting session.

The aim of this research is to find out learner identity and difference through English club meeting at Megarezky Universitas. There were several areas in analyzing students identity and difference based on, as (Toohey \& Norton, 2012), list of learners' identities covers "personalities, learning styles, motivation, and other unique characteristics of individual learners", while in the scope of this research, to identify learners' identity and differences might cover four areas; motivation, learning strategies, learner autonomy, and cross-linguistic influence. There are four factors which might influence students in learning English, these are; motivation, learning strategies, learner Autonomy, and cross-linguistic influence.

The research problems on this research was about students' learner identity and difference at E-Comer English club meeting, it will beneficial for lecturer to understand their students' identity, character and difference of their learning strategies, motivation, and learner autonomy.

\section{B. REVIEW OF LITERATURE}

A number of researchers had been conducted to find out the advantages of English club meeting for students English performance. First, (Sandityana, 2019)under the title "Practices of English club in facilitating the improvement speaking ability at SMAN 1 Trenggalek", she founded that the advantages of SMANESA English club activities were increasing students' 
self-confidence, pronunciation, grammar, speaking, critical thinking, creativity, knowledge, that can express their thought and thinking.

In addition, another recent research about "the effectiveness of English Club as free voluntary speaking activity strategy in fostering speaking skill in Saudi Arabia context" is written by (Elnadeef \& Abdala, 2019) who found that English club assists Saudi students helped students to reduce anxiety in speaking through fun circumstance. It also helps students to build their critical thinking in persuasive and argumentative skills.

Furthermore, the experiment research comes from (Zema, 2018) about "the effect of English language club activities on students' listening and speaking skills and attitude change: Woldehane preparatory school in focus", revealed that English language clubs have improved students' test result of listening and speaking which is proved by the speaking and listening test. It also showed positive students' attitude in club activities.

\section{Learner Identity}

Identity always relates with the question "who are you?", "who you are?", "where do you come from?", and so on. However, to identity someone is not only asking the name and nationality but it might be more than that. It related with their life experience, attitude life style, preference, believe and so on. (Murray \& MaryAnn, 2010) stated that identity was individual's perspective of themselves and the place that they live in. In this case, it reflects on their experience, circumstance and point of view, believed can create their personal identity.

Furthermore, "learners' past and present experience can influence knowledge about their relationship to the society and culture of the language that they had learned, and therefore they utilize, resist, or even create opportunities to use the language" (Murray, 2011) (Murray \& MaryAnn, 2010). This past and present experience include motivation, learning strategies, learner autonomy, and cross-linguistic influence. The other researchers' categorists learners' identity in : nationality, gender, race ethnic, family role, believes, situated roles, and class in society (Murray, 2011; Toohey, 2011). All these experiences in the past were created students' identity, that every student placed in one class shape learners in one class that were from different environment and experience.

\section{English Meeting Club}

An English meeting club is an activity to organize some people which have same purpose and interest, which has set regular schedule, activity and rules in it. An English club is a meeting for members who can apply and use English in informal setting which is an opposite learning setting rather than school or classroom setting. Even though the setting of this class used classroom or school circumstance, activities in English club meeting are fun, enjoyable and 
entertaining. It relaxes and engages students to speak especially English. This state mentis strengthened by (Elnadeef \& Abdala, 2019), which stated that "the English club has striven to help learners avoiding the mental block by engaging in fun communicative club-style activities in English".

Furthermore, the advantages of English club, according to Carter and Nunan in Elnadef \& Abdala (2019) said that it can give opportunity for students to use English in the real situation, practice English based on the authentic situation, increase students' self confidence among peers, increase student' social skill ability, and create friendship relations between peers. Those advantages are believed, English meeting member at E-comer English club meeting can achieve it.

\section{METHOD}

\section{Respondents}

The respondents on this research were students from Megarezky University, who regularly attended E-comer English club meeting for every Saturday from 10 am to $1 \mathrm{pm}$. There were around twenty students as respondents in this research who come from 20 study programs at Megarezky University. In addition, 5 respondents were interviewed to gain more information related to the topic.

\section{Instruments}

The instrument of this research used observation and interview sheet. The researchers attended of E-Comer English club meeting and fill the field note in every session of their attended. An additional data of this research, the researchers interview some students which help the research to conclude and justify of students' learner identity and difference. In interview session, students can express their opinion, thought and perspective, while for the researcher, it helps to clarify and justify some questions which might appear during observation session.

\section{Procedures}

The procedure on this research was started by choosing respondents. Purposive random sampling was a method to choose the respondents who came regularly at E-Comer English club meeting. Next, the researcher did the observation for seven weeks and write field note for every session of meeting. After that, interview sheet was needed for clarify some of questions which appeared during observation sessions. 
Volume 6, Number 02 December 2020

\section{Data Analysis}

In this research, the researcher applied qualitative approach to analyze the data. The collected data were presented, analyzed, discussed and interpreted. Then, these were transformed into finding and discussion section.

\section{FINDINGS AND DISCUSSION}

In this section, it covers four areas to identify learners' identity and difference through motivation, learning strategies, learner autonomy, and cross-linguistic influence.

\section{Motivation}

The respondents on this research showed some motivation theory based on (Dörnyei \& Ushioda, 2011)related with their activities during the E-Comer club meeting session. These theories are:

The integrative orientation by Gardner (Dörnyei \& Ushioda, 2011) stated that integrative orientation was "willingness to be like valued members of the language community". It indicated that group club community impact positively for members to shows their ability among group members. Members in group club tend to show their ability if they were in their group community. It showed from the researchers' observation in E-comer English meeting that members of the groups tended to speak English and show their excitement during the English meeting club. One statement from interview written that "I feel excited to speak especially with my friends in this club" (a.3). It indicates the members in a group club tend to show their excitement when they are together with their friends in meeting club. As same as with Gardner (cited in Dornyei, 2001) stated that motivation could gain from parents, family, and friends. In this case, friends' factor in club meeting can motivate students to speak English.

Another motivation appeared of this observation that "Goal-related dimension" based on (Dörnyei \& Ushioda, 2011). It intended to focus on personal goal of the members of the meeting club. There were several reasons why the students attend meeting club every Saturday. There were internal and external factor of motivation, external motivation which were coming from researchers' observation showed that one of the segment in meeting club that announcement of the best group performance at the end of the meeting club. In this session, the committee will announce the best group who give best performance than other groups and they got reward. This goal triggered all members in the group to be active and support each other to make their group become a winner. (Pearsall et al., 2010) researched, found the reward system in group created different motivation among them, and of course it related to 'external stimuli on team outcomes'. It indicated that students' motivation come from external factor 
because effort to get reward. In this case, this motivation type was temporary due to the setting or members of the group, opposite point of view with internal motivation which was believed much stronger and long lasting because it comes from personal motivation.

Furthermore, the committee role of this meeting club was also essential to maintain students' motivation. This is in line with (Cohen, 2014) statement that maintaining and protecting students' motivation were important to encourage their self-evaluation. In this case, the committee members as mentor which mostly senior in this meeting club, can give them tutorial, during the observation. Guidance from committee help the new members adapt and build their confidence to speak English. During the time, this member can help other members based on their experience when they got guidance from their senior. It also encouraged students to do self-evaluation which reflected with their experience. Their mentoring helped new members adapt and find their self-confidence, it also helped students to feel satisfied to themselves and encourage them to learn more. One of the members said that "I feel happy to help new members and motivate them to speak, because they are mostly shy to speak English".

\section{Learning Strategies}

Based on the theories of learning strategies (Cohen, 2014), he divided learning strategies into four parts; 'retrieval strategies, rehearsal strategies, coping strategies, and communication strategies'. From these four learning strategies, the group discussion activity had been noted that there were two learning strategies involved in it; 'coping strategies and communication strategies'.

(Cohen, 2014) divided out coping strategies into two, there were "compensatory strategies" and "cover strategies". Compensatory strategies were tended to simplify the English word that they did not know (Cohen, 2014), which was one of learning strategies that used by students in English meeting club. During the classroom observation, students tended to explain difficult word to their simple English, it causes of their limitation range of vocabularies. For Example, when committee said "it's simply because they cannot cope their time in doing homework". Students got a difficult word "cope", and when they found the meaning they tend to use "manage" rather than "cope" which was more familiar for them. In this case, students tend to simplify their communication by merely used words which were familiar among them.

Another example of compensatory strategies that learners applied in this research because overgeneralization grammar in communication. Based on research observation, students used this technique especially when they communicate to each other. They tend to ignore using grammar and focus on the communication or content of they want to communicate. For 
example of compensatory strategies that students' showed in E-comer English meeting was when they speak about their past experience, they said "when I am a kid, I am very naughty". He used ungrammatical rules and make simplify their grammar by using simple present rather than used simple past. This indicated that they only focus on the content and the flow of their communication rather than the grammar aspect. They seem to have to think fast to produce sentence immediately, they were incompetent to consider about grammar aspect while they speak. They might consider thinking about vocabularies and contents that they what to deliver to listener.

In addition of Cohen theory about learning strategies that appeared during the observation was, 'cover strategies'. It 'involves creating an appearance of language ability not to look unprepared, foolish, or even stupid'. Relating to this theory of 'not to look unprepared' students tend to speak much but out of from the topic. They tried to hide their unprepared by speak a lot without really understand about the topic. The students were difficult to get involved in the topic in more detail, they tend to speak in general aspect by giving longwinded explanation and did not answer the questions which were given by committee to discuss in their group. Another strategy that students tend to use in cover strategies was kept silent, quiet and inactive during the meeting. Students tried to avoid speaking due to the negative judgment from their other members. They merely listen but avoid responding by giving comments or discuss actively during the club meeting. She said "I am afraid of speaking because I do not want my friends laughing on me" (Student X interview). It indicates that feedback from their friends affect them to hold themselves to speak because they avoid judging stupid or foolish by their friend.

Moreover, another strategy that students' used in communication was code mixing and code switching, however, the used of code mixing became more dominant rather than code switching. This technique helped students to express their thought due to lack of vocabularies range. As (Nunan, 2015) define it as 'a phenomenon of switching from one language to another in the same discourse'. It indicated that code mixing technique had a function as a medium between the first language and the target language. In this case, using the first language (L1) helps them to convey their though in group work discussion. For example the use of code mixing in group discussion was "my parents also menekanku in doing homework"(field note data). The word menekank $u$ was come from student's L1, she used this word because she found difficulty to find sufficient English vocabularies or lack of vocabularies. Rather than she stopped doing communication because of one word, she decided to use code mixing technique in her communication which help her to express her thought. 


\section{Learner Autonomy}

Regarding on learner autonomy, the researcher found it several learner autonomy practiced during the meeting club. Benson, the responsibility that students had in learner autonomy including the control of the cognitive process of effective self-management in learning, which some students assumed that learner autonomy means learner will learn by themselves without guidance from teachers or learning without teachers. However, (Benson, 2011)listed some of guidance of learner autonomy which was namely "three dimensions of control in language learning": first; learning management and behavior, second; learning cognitive process and psychology, third; learning content and situational.

However, from these three dimensions of control in language learning by Benson, it was noted that only learning management and behavior was appeared in this English club meeting session, especially for social and affective strategies of learning. As (Benson, 2011) stated that social and effective strategies was the learning control of learners I terms to other people and to their self, whereas activities were involved in it; 'asking questions, cooperating with others, and empathizing with others'. Based on writer observation, these three activities were applied by learners in meeting club. These three activities were common to notice in the middle of discussion which showed the interaction between the lead of discussion and group members. Some of them were asked about the topic which might be hard for them to understand. It could be the questions or the text from the topic that they had to discuss in that day. They were merely about clarification of their interpretation of their understanding about the topic. For instance. "What do you mean in the second questions?, Do you mean all levels of education should be banned homework?". In this case, one member on that group was asking for clarification about the statement from the questions in the topic.

Another case, the group member showed the cooperative attitude toward others by discussing and sharing their opinion of the topic and attempted to formulate all opinions of the group members into a group discussion. In this process, the result of the earlier small group discussion will bring into a large one group discussion. Every group presented their group result about the topic and every member in every group could agree or reject other groups opinion. However, being a person who represent their group into a large group was not easy for some of students. They tend to scare, afraid, anxiety and even reject to speak. Others member in this group showed some supports by encouraging them and showing attitudes by listening them carefully even though they did not speak well and tend to read the paper. They showed their support by not mocking, laughing, and showing impolite attitudes. They showed their 
cooperative attitudes towards others by understanding they also did that before and acknowledge it on the process of learning.

The social methods were appeared in this club, the affective method was also shown in group meeting. Deep breathing (Benson, 2011)was one of strategies to lowering his/her anxiety especially used by students who fill nervous. The person who chose as a representative in their group tend to use this technique to release their anxiety to speak in large group of discussion session. One of representative applied this method, and it helped him to continue his speak until end, when he had chosen as a speaker in his group. Another method that students used was 'using laughter'. This method was very effective to hide their anxiety by laughing, mostly after they laugh in the beginning of the session, they mostly can control their self and help them to reduce their anxiety.

\section{Cross-linguistic Influence}

Relating cross-linguistic influence, the use of language in terms of formal and informal language setting influenced students' language in English meeting club. As (Zabrodskaja, 2013)j mentioned about the difference between formal and non-formal situation in learning environment can affect cross-linguistic influence. Related to English meeting club. it can be categorized as non-formal learning environment, while classroom can be categorized as formal learning environment. Both of had strength point, classrooms provided learner in the formal setting, act and used language in appropriate ways. However, (Watson-Gegeo \& Nielsen, 2008)had strong argument about that and stated 'classroom might not be rich as another context in student's life they were not inherently unnatural'. The limitation of learning process in classroom was used in certain context which mostly students were not used in their daily life. Meanwhile, the English meeting club provided naturalistic setting of communication, which they tend to use language to their friends in natural setting.

Another aspect of cross-linguistic influence which can be easy to find out of students' interaction in English meeting club was the first language intervention of the target language, between Bahasa and English. There was positive perspective from both of language; L1 and L2 which have similarity. This is in line with (Zabrodskaja, 2013) stated that the close relationship between the first and the target language shown better learners' result referred to acquirement of the target language. As some vocabularies in Bahasa are close relation in terms of pronunciation and meaning. For example, quality and 'kualitas', analyze and 'analisa', photo and 'foto'. These similar vocabularies helped learners to acquire target language, which they might focus on other vocabularies rather than similar vocabulary However, these vocabularies affected to learners' pronunciation. They tend to use their first language pronunciation rather than target 
language. As example in English meeting club, especially the new members, they tend to pronounce rather than /'fəutəひ/. They were preferred to used Bahasa Indonesia accent rather than English pronunciation. Some members tend to ignore this pronunciation mistake, they thought as long they can understand each other, it was enough. But it might be an issue if they speak or use Bahasa accent with other people who cannot understand their pronunciation. In this case, they find it difficult to understand each other even they speak same language, English.

\section{E. CONCLUSION}

Analyzing learners' identity and difference not only it was through classroom interaction but also it was through informal setting English meeting club. The process to identify learners' identity of this research covered four areas such as motivation, learning strategies, learner autonomy, and cross-linguistic influence. In terms of motivation, there were three factors influence students' motivation in learning such as group community values, students' goal, and maintaining and protecting motivation. While, in learning strategies, students in English meeting club applied several learning strategies such as coping, covering, doing communication and code mixing strategies. In learner autonomy, students' in this meeting club tend to decide and take responsibility on their process of learning. And the last, in terms of cross-linguistic influence, students tend to speak casually in informal setting rather than speak formally which related with grammatical and pronunciation rules. The result of this information was a beneficial information for teacher to decide the best learning strategies which one of it by using code mixing strategy applied in English classroom and also can cultivate students' motivation through several methods.

\section{REFERENCES}

Benson, P. (2011). Researching autonomy. In Teaching and researching: autonomy in language learning.

Cohen, A. D. (2014). Strategies in learning and using a second language. In Strategies in Learning and Using a Second Language. https://doi.org/10.4324/9781315833200

Dörnyei, Z., \& Ushioda, E. (2011). Teaching and Researching Motivation 2nd edition. In PEARSON Education Inc.

Elnadeef, E. A. E., \& Abdala, A. H. E. H. (2019). The Effectiveness of English Club as Free Voluntary Speaking Activity Strategy in Fostering Speaking Skill in Saudi Arabia Context. Online Submission.

Kolb, A. Y., \& Kolb, D. A. (2012). Learning Identity. In Encyclopedia of the Sciences of Learning. 
Volume 6, Number 02 December 2020

https://doi.org/10.1007/978-1-4419-1428-6_229

Murray, D. E., \& MaryAnn, C. (2010). What English language teachers need to know:

Understanding learning. In What English Language Teachers Need to Know: Understanding Learning. https://doi.org/10.4324/9780203846339

Nunan, D. (2015). Teaching English to Speakers of Other Languages. In Teaching English to Speakers of Other Languages. https://doi.org/10.4324/9781315740553

Pearsall, M. J., Christian, M. S., \& Ellis, A. P. J. (2010). Motivating Interdependent Teams: Individual Rewards, Shared Rewards, or Something in Between? Journal of Applied Psychology. https://doi.org/10.1037/a0017593

Sandityana, D. (2019). Practices of English club in facilitating the improvement of students' speaking ability at SMAN 1 Trenggalek. IAIN Tulungagung.

Toohey, K., \& Norton, B. (2012). Language Learner Identities and Sociocultural Worlds. In The Oxford Handbook of Applied Linguistics, $(2 \mathrm{Ed}$.). https://doi.org/10.1093/oxfordhb/9780195384253.013.0012

Watson-Gegeo, K. A., \& Nielsen, S. (2008). Language Socialization in SLA. In The Handbook of Second Language Acquisition. https://doi.org/10.1002/9780470756492.ch7

Zabrodskaja, A. (2013). Crosslinguistic influence in language and cognition. Scott Jarvis and Aneta Pavlenko (2008) New York and London: Routledge. Pp 287. ISBN 0805838856. Sociolinguistic Studies. https://doi.org/10.1558/sols.v6i3.603

Zema, Z. (2018). The Effect of English language club activities on students' listening and speaking skills and attitude change: Woldebane preparatory school in focus. Arba Minch University. 